\title{
PDGFC wt Allele
}

National Cancer Institute

\section{Source}

National Cancer Institute. PDGFC wt Allele. NCI Thesaurus. Code C104750.

Human PDGFC wild-type allele is located in the vicinity of $4 q 23$ and is approximately 211

$\mathrm{kb}$ in length. This allele, which encodes platelet-derived growth factor $\mathrm{C}$ protein, is involved in both embryonic development and growth factor signaling. 